\title{
Makna Simbolik Budaya Marhabaan bagi Kalangan Nahdlatul Ulama
}

\author{
Wawan Setiawan ${ }^{*}$ \\ 1 UIN Sunan Gunung Djati Bandung, Indonesia; e-mail: wawandandia@gmail.com \\ * Correspondence
}

Received: 2020-04-11; Accepted: 2020-12-25; Published: 2020-12-30

\begin{abstract}
This paper describes the relationship between Islam and local culture. The purpose of this study was to identify and analyze the process and symbolic meaning of the marhabaan culture among Nahdlatul Ulama, precisely at Al-Quwwah Islamic Boarding School, Bandung City. The method used in this research is qualitative, which clearly defines various kinds of research procedures, so that it will produce descriptive data from what is observed in marhabaan cultural activities, both written and oral. This method aims to know and understand a phenomenon experienced by research subjects such as motives, behavior, opinions, interactions, language, actions, motivation and so on naturally by using various natural methods. The results of this study explain the marhabaan process from beginning to end, then explain the shaving of baby's hair, the symbolic meaning of banana, the symbolic meaning of menyan, the symbolic meaning of ulen (glutinous rice), the symbolic meaning of traditional cakes, and the symbolic meaning of water. All of this emphasizes that there is a traditional combination from the community between Islamic teachings and local culture.
\end{abstract}

Keywords: mass organization; nahdlatul ulama; religious behavior; religious culture; sociology of the family

Abstrak: Tulisan ini menjelaskan hubungan Islam dengan budaya lokal. Tujuan penelitian ini adalah untuk mengetahui dan menganalisa proses dan makna simbolik budaya marhabaan di kalangan Nahdlatul Ulama tepatnya di Pondok Pesantren Al-Quwwah Kota Bandung. Metode yang digunakan dalam penelitian ini adalah kualitatif, yaitu mendefinisikan secara jelas berbagai macam prosedur penelitian, sehingga akan menghasilan data-data deskriptif dari apa yang diamati dalam aktivitas budaya marhabaan baik berupa tulisan ataupun lisan. Metode ini mempunyai tujuan untuk mengetahui dan memahami suatu fenomena yang dialami oleh subjek penelitian seperti motif, perilaku, pendapat, interaksi, bahasa, tindakan, motivasi dan lain sebagainya secara alamiah dengan menggunakan berbagai metode alamiah. Hasil penelitian ini menjelaskan tentang proses marhabaan dari awal sampai akhir, kemudian menjelaskan pencukuran rambut bayi, makna simbolik pisang, makna simbolik menyan, makna simbolik ulen (nasi ketan), makna simbolik kue tradisional, dan makna simbolik air putih. Semua itu menegaskan bahwa terdapat kombinasi yang mentradisi dari masyarakat antara ajaran Islam dan budaya lokal.

Kata Kunci: budaya keagamaan; organisasi massa; nahdlatul ulama; perilaku keberagamaan; sosiologi keluarga

\section{Pendahuluan}

Islam sebagai agama dakwah tidak hadir dalam ruang yang hampa, ia bersentuhan dengan faktorfaktor lain seperti budaya yang begitu melekat di tengah-tengah masyarakat. Generasi-generasi Islam mendapatkan tradisi atau kebudayaan yang diberikan oleh para pendahulunya secara turun-temurun. Karena masyarakat memiliki berbagai macam kebudayaan, dan kebudayaan itu sifatnya berkembang (Sambas \& Aripudin, 2007). Islam hadir bukan untuk menghapus tradisi yang baik yang sudah ada. Justru kehadiran Islam adalah untuk melengkapi dan menyempurnakan tradisi yang ada di Nusantara ini (Rahman, 2013). Begitu pula dalam menghadapi tradisi dari luar terdapat prinsip yang menjelaskan 
AlMuhafazhatu 'Ala al Qadiimil al Shalih Wa al Akhzu Bi al Jadiidi al Ashlah (Memelihara tradisi lama yang baik dan mengambil tradisi baru yang lebih baik). Mengingat tujuan pengambilan dan pengembangan budaya adalah untuk perbaikan akan menjadi modal bagi pengembangan budaya yang ada. Oleh karena itu, nilai-nilai Islam tidak hanya milik otoritas institusi-institusi lembaga-lembaga secara formal, tetapi juga melebar dan mengjewantah bahkan menjadi ruh dalam tradisi budaya masyarakat (Negara, 2017).

Tradisi yang senantiasa dipertahankan masyarakat Jawa Barat khususnya masyarakat Bandung ialah budaya marhabaan. Marhabaan atau pembacaan kitab al Barzanji secara bersama-sama merupakan tradisi yang sangat popular di masyarakat Jawa Barat khususnya di Kota Bandung. Kegiatan tersebut merupakan bagian dari khazanah Islam khas di kalangan pesantren yang hidup lestari sejak dulu dan terus dipertahankan (Negara, 2017). Berdasarkan sejarah dalam literatur Islam penyebaran maulid Al-Barzanji ditebarkan oleh para Sayyid, sekelompok masyarakat Arab dari Yaman yang sangat berpengaruh proses datangnya misi Islam dan mereka inilah yang mawarnai berbagai metode ritual di Indonesia (Bachmid, 2014).

Hal yang sama juga di kalangan masyarakat sekitar pesantren ataupun masyarakat yang berbasis Nahdlatul Ulama (NU). Budaya marhabaan telah diamalkan di sudut-sudut yang paling jauh dari kota. Tidak hanya di kawasan pedesaan atau diperkampungan yang merupakan basis inti Nahdlatul Ulama namun juga di kawasan perkotaan yang lebih medernis dan heterogen di Kota Bandung. Masyarakat NU sangat merawat budaya marhabaan tersebut di samping itu budaya seperti ini sudah mendarah daging dalam kehidupan sehari-hari dan di tengah kehidupan sosialnya (Wawancara dengan HT, pimpinan pesantren, Bandung, 03/05/2020). Selain sebagai ritual rutin yang dilaksanakan setiap acara besar seperti peringatan maulid Nabi Muhammad saw, acara pindah rumah, acara aqiqah dan semacamnya, juga dilaksanakan pada setiap malam jum'at. Lebih dari itu, acara marhabaan telah menjadi salah satu perekat dan mobilisasi sosial masyarakat karena dilakukan secara rutin dan dilakukan secara berjama'ah, baik di masjid, mushalla maupun di rumah-rumah yang mendapatkan giliran untuk acara tersebut (Abdul Fatah, 2008).

Selain itu budaya marhabaan merupakan tradisi yang di dalamnya terdapat simbol-simbol yang perlu digali lebih mendalam lagi. Simbol-simbol yang terdapat pada kebudayaan memiliki sifat konkret, umum dan terserap. Sedangkan kegamaan memiliki simbol-simbol yang dipercaya oleh seseorang bahwa dengan adanya simbol-simbol dalam keagamaan akan memperkuat keyakinan mereka dalam beragama (Dillistone, 1986). Oleh karenanya, simbol-simbol budaya dan keagamaan ini bisa dikaji oleh pendekatan etnografi. Studi etnografi sebagai fenomena keagamaan ini mencoba menelaah terhadap salah satu produk budaya bagi lahirnya konsep dakwah yang berpangkal dari budaya lokal (Mulyana, 2002; Wibisono, 2013). Budaya marhabaan sebagai etnografi mencoba menelaah dan menemukan prosesi dan makna sebuah simbol yang terdapat pada aktivitas budaya marhabaan secara menyeluruh, baik dari segi bacaannya (barzanji), interaksinya, bahasa yang digunakannya, pengalamannya, kepercayaannya, sistem nilai yang dianutnya dan lain sebagainya.

Relevansi penelitian mengenai budaya marhabaan yang sudah dilakukan misalnya oleh Nur Rosyid (Rosyid, 2012). Hasil penelitiannya adalah perkembangan tradisi shalawatan yang berkembang di Surakarta dan sekitarnya telah mengalami perubahan. Tradisi memang tidak semestinya ditempatkan dalam oposisi dengan modern. Tradisi memang bersifat kontekstual. Proses kontekstualisasi tradisi berlangsung melalui komodifikasi. Proses tersebut dibangun melalui dua media, yaitu media perekaman dan manggung. Selain itu, Habib sebagai artis membangun audiences dengan cara penyamaan nama melalui serangkaian peresmian.

Selanjutnya, proses komodifikasi ini membawa perubahan relasi yang dalam dunia bisnis disebut sebagai "religious franchise". Kecocokan dengan konsep franchise tersebut, terletak pada label "Ahbabul Musthofa", produk shalawat, dan manajemen cara pentas. Semua itu dilakukan melalui standarisasi praktik dan produk. Dengan demikian, secara sadar atau tidak, logika bisnis global tentang waralaba, ikut berdampak pada kontekstualisasi tradisi shawalat.

M. Junaid (Junaid, 2005) melakukan penelitian tentang tradisi Barzanji Sya'ban masyarakat Bugis Wajo Tanjung Jabung Timur. Berdasarkan penelitiannya dilakukan secara antropologi dapat 
ditemukan bahwa pembacaan mauled justru dilakukan pada bulan Sya'ban. Pelaksaannya adalah selama sebulan penuh dengan waktu yang bergiliran dari satu rumah ke rumah yang lain. Pembacaan dalam bulan Sya'ban seperti ini dilakukan sebagai bentuk dari rasa Syukur kepada Allah atas segala nikmat yang diberikan oleh Allah.

Eka Octalia Indah Librianti (Librianti \& Mukarom, 2019) dalam tesis yang berjudul "Budaya Tahlian Sebagai Media Dakwah", menunjukkan bahwa salah satu media untuk berdakwah salah satunya adalah tadisi tahlilan, yang mana di dalamnya terdapat nilai-nilai keagamaan dan nilai-nilai sosial. Gayda Bachmid (Bachmid, 2014) berjudul "Kitab Barzanji dalam Perspektif Masyarakat Muslim di Manado, Sulawesi Utara, menunjukkan bahwa aspek-aspek intralingusitik berkaitan erat dengan unsur-unsur ekstralingusitik bertemu dalam tema-tema sosial seperti nilai kehormatan, kebersamaan, persaudaraan, dan penghargaan. Tema kultural mengandung nilai ketenangan kebahagiaan, dan kesyukuran. Tema metafisik (filosofi) mengandung nilai-nilai kepercayaan, keimanan dan keyakinan. Hubungan penelitian ini dengan penelitian yang akan dilaksankan adalah terletak pada budayanya, sedangkan perbedaannya terletak pada kajian yang dibahasnya. Berdasarkan beberapa relevansi dari penelitian terdahulu bahwa penelitian ini akan menjelaskan mengenai prosesi dan makna simbolik budaya marhabaan di kalangan Nahdlatul Ulama tepatnya di Pondok Pesantren Al-Quwwah Kota Bandung.

\section{Metode Penelitian}

Metode yang digunakan dalam penelitian ini adalah kualitatif. Metode ini mendefinisikan secara jelas berbagai macam prosedur penelitian, sehingga akan menghasilan data-data deskriptif dari apa yang diamati dalam aktivitas budaya marhabaan baik berupa tulisan atau lisan (Mustari \& Rahman, 2012). Dengan demikian, berbagai macam faktor-faktor yang berupa tulisan, lisan seta dokumendokumen yang diamati bisa dianalisis dan ditelaah suapaya mengetahui serta menemukan sebuah makna yang ada di dalamnya.

Metode ini mempunyai tujuan untuk mengetahui dan memahami suatu fenomena yang dialami oleh subjek penelitian seperti motif-motif, perilaku, pendapat, interaksi, bahasa, tindakan, motivasi dan lain sebagainya secara alamiah dengan menggunakan berbagai metode alamiah. Sesungguhnya paradigma ini merupakan pendalaman dari fenomena sosial artinya lingkungan sosial yang di dalamnya terdapat pelaku, kejadian, tempat dan waktu. Fenomena sosial tersebut dilakukan dalam penelitian kualitatif yang dikembangkan berdasarkan beberapa pertanyaan dasar, yaitu sebagai berikut: (a) Apa dan bagaimana aktivitas itu bisa terjadi. (b) Siapa saja yang terlibat dalam aktivitas tersebut. (c) Sejak kapan aktivitas tersebut berlangsung. (d) Dimana tempat aktivitas itu berlangsung.

Metode ini bertujuan bertujuan untuk menemukan hasil yang dapat dipercaya. Agar hasilnya dapat dipercaya dan dapat di pertanggungjawabkan, maka diperlukan beberapa persyaratan seperti syarat data, teknik pengumpulan data, pengelolaan data-data serta analisis data-data yang diamati (Ghony F., 2016). Penelitian ini termasuk kepada penelitian lapangan, yang mana peneliti harus terlibat secara langsung dalam proses kegiatan yang sedang berlangsung, agar bisa mengetahui secara lebih dalam interaksi sosial dalam suatu kelompok atau kelembagaan yang ada dilingkungan masyarakat tertentu (Akbar \& Usman, 2006).

\section{Hasil Penelitian}

\section{Perkembangan Islam di Tatar Sunda}

Islam di Tatar Sunda muncul dalam wajah yang lebih egaliter, harmonis, jauh dari kekerasan structural maupun kultural dan memiliki kepribadian yang jauh lebih dari sekedar Islam dalam arti sebatas fenomena saja (Sumpena, 2012). Islam memasuki Tatar Sunda dengen penuh kedamaian, memberikan nilai-nilai spiritual bagi masyarakat Sunda yang telah memiliki sifat banif dengan penyembahan hanya pada satu tuhan saja (monoteisme) (Raffles, 2018). Kehadirannya diterima dengan penuh sukacita, tidak ada pedang dan darah yang dikorbankan, tidak ada nyawa dan korban jiwa yang 
melayang. Semua berjalan sebagaimana kehendak tuhan hingga akhirnya munculah istilah di masyarakat bahwa Islam itu Sunda dan Sunda itu Islam.

Dalam Carita Purwaka Caruban Nagari disebutkan bahwa daerah-daerah di Tatar Sunda yang berhasil diislamkan oleh Sunan Gunung Djati selain Cirebon adalah daerah Kuningan, Sindangkasih, Talaga, Luragung, Ukur, Indralaya, Bantar, dan Imbanganten. Galuh dan Sumedang diislamkan oleh Cirebon pada masa Sunan Gunung Djati. Daerah Luragung diislamkan tahun 1481 M. Daerah Kuningan, Talaga, Galuh dan daerah sekitarnya terjadi pada 1530 M. Adapun daerah Rajagaluh disilamkan tahun $1528 \mathrm{M}$ dan $1530 \mathrm{M}$ (Lubis, 2011).

Menurut cerita rakyat Sindangkasih (Majalengka), daerah ini disilamkan oleh utusan Cirebon dibawah pimpinan Pangeran Muhammad dan Siti Armila. Ratu Sindang Kasih yang bernama Nyai Rambut Kasih menolak diislamkan tapi memberikan kebebasan kepada rakyatnya yang mau masuk Islam. Menurut Carita Purwaka Caruban Nagari, Walangsungsang pada masa akhir hidupnya mengembangkan Islam di daerah Priangan Selatan. Menurut tradisi sumber di Garut, Kian Santang sebagai putera raja Padjajaran (Prabu Siliwangi). Ia berselisih dengan ayahnya, tetapi akhirnya disepakati Kian Santang diberi keleluasaan menyebarkan Islam di seluruh kerajaan Sunda. Berdasarkan sumber tradisi dari Ciamis, masuknya Islam ke daerah Galuh (Ciamis) dengan pangeran Mahadikusumah atau Maharaja Kawali. Pangeran Mahadikusumah terkenal sebagai ulama yang sangat dipercayai di Cirebon. Patilasan berupa ampak batu yang mungkin bekas bangunan masjid di pulau danau Panjalu (Ciamis) menunjukan permulaan Islam di daerah itu (Sujati, 2019).

Islam masuk ke daerah Sumedang melalui cara perkawinan. Pangeran Santri yang dikenal sebagai penguasa daerah Sumedang pertama yang beragama Islam. Pangeran Santri dari pihak ibu adalah keturunan raja Padjajaran dan dari pihak ayah keturunan Sunan Gunung Djati (Wanta, 1991).

Nina Herlina Lubis menemukan bahwa stimulusnya adalah pangkal masuknya Islam ke wilayah Priangan dari Cirebon; sedangkan masuknya Islam ke wilayah Banten Selatan, Bogor, dan Sukabumi dari Banten. Dengan demikian, wilayah Jawa Barat (Tatar Sunda) dibagi atas dua bagian penyebaran Islam yaitu bagian Barat Bagian Barat dengan pusatnya ialah Banten Selatan, Jakarta, Bogor, dan Sukabumi. Bagian Timur denga pusatnya Cirebon, dan daerah penyebarannya adalah Kuningan, Majalengka, Indramayu, Subang, Cianjur, Sumedang, Garut, Tasikmalaya, Ciamis, dan Bandung (Lubis, 2011).

\section{Tradisi Islam di Tatar Sunda}

Islam di Tatar Sunda muncul dalam wajah yang lebih egaliter, harmonis, jauh dari kekerasan structural maupun kultural dan memiliki kepribadian yang jauh lebih dari sekedar Islam dalam arti sebatas fenomena saja (Sumpena, 2012). Islam memasuki Tatar Sunda dengen penuh kedamaian, memberikan nilai-nilai spiritual bagi masyarakat Sunda yang telah memiliki sifat hanif dengan penyembahan hanya pada satu tuhan saja (monoteisme) (Raffles, 2018). Kehadirannya diterima dengan penuh sukacita, tidak ada pedang dan darah yang dikorbankan, tidak ada nyawa dan korban jiwa yang melayang. Semua berjalan sebagaimana kehendak tuhan hingga akhirnya muncullah istilah di masyarakat bahwa Islam itu Sunda dan Sunda itu Islam.

Masyarakat Sunda memiliki varian karakter sendiri dalam tatanan amalan yang sudah melekat menjadi tradisi tidak terpisahkan dari pelaksanaan tahunan, bulanan, mingguan bahkan harian yang dilakukan oleh masyarakat (Koentjaraningrat, 2004). Praktek amalan ini adalah buah pandang cita, rasa, karsa pemahaman masyarakat terhadap sebuah nilai ajaran moral, diyakini dan dipraktekkan dengan kemasan tata cara yang beragam. Salah satu praktek yang sudah lama melakat di pemahaman masyarakat Sunda yaitu tradisi marhabaan yang dilaksanalan pada acara-acara besar seperti Mauludan, Aqiqahan, pernikahan, dan pada setiap malam jum'at.

Marhabaan merupakan sebuah tradisi yang hidup di kalangan masyarakat Sunda dalam rangka mengagungkan kelahiran Rasulullah SAW., tepatnya pada bulan Rabiul Awwal. Nama Marhabaan ini berasal dari bahasa Arab marhaban, karena dalam tradisi ini biasanya dibacakan shalawat 'ya nabi salam 'alaika 'mahall al-Qiyam'. Shalawat ini di masyarakat Sunda lebih dikenal dengan 'marhaba,' oleh karena itu tradisi ini dikenal dengan 'marhabaan'. Sama halnya dengan tradisi yasunan, 
dinamakan yasinan karena yang dibaca adalah surat yasin. Tradisi ini sering juga disebut dengan muludan karena dilakukan pada bulan Rabilul Awwal yang dalam masyarakat Sunda bulan tersebut lebih dikenal dengan bulan Mulud, diambil dari bahasa Arab maulid atau maulud (Wahidi, 2015).

\section{Proses Marhabaan}

\section{Kegiatan Awal}

Kegiatan awal marhabaan ini meliputi persiapan. Maksudnya adalah berkaitan dengan waktu yang baik untuk memulai kegiatan acara marhabaan ini dengan mengkondisikan kesempatan imam, anggota partisipan, dan masyarakat setempat. Kemudian disiapkan perlengkapan dan hal-hal yang dibutuhkan demi jalannya tradisi ini. Prosesi marhabaan memerlukan berbagai persiapan mulai kuekue, hidangan, menyan, dan tentu saja kitab al-Barzanji yang digunakan untuk membaca. Setelah hal itu selesai maka imam, para santri dan masyarakat memasuki masjid tempat diadakannya acara marhabaan. Ketika semuanya telah hadir maka imam memulainya dengan membacakan do'a keselamatan untuk semua kaum muslim, dan mengirimkan surah al Fatihah kepada Nabi Muhammad Saw, para keluarganya, sahabatnya, serta untuk kaum muslimin yang sudah meninggal (Wawancara dengan IT, pengajar pesantren, Bandung, 03/05/2020).

Kegiatan Inti

Setelah kegiatan awal selesai maka masuklah kepada kegiatan inti maka imam pun memulai pembacaan kitab al-Berzanji yang diawali dengan bacaan

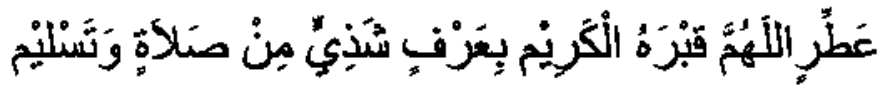

kemudian dijawablah seluruh partisipan dengan ucapan

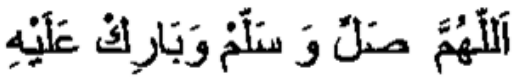

Kemudian dilanjutkan prolog dan pembukaan kitab al Barzanji berjumlah empat pasal. Ketika imam membaca pasal yang keempat ada bacaan Mahallul Qiyam (berdiri ketika membaca shalawat) sehingga partisipan seluruh yang hadir berdiri sambil membaca shalawat secara berjamaah dengan nada dan irama. Mahallul Qiyam ketika membaca shalawat kepada Nabi. Para partisipan sengaja berdiri dengan maksud ingin mengungkapkan ekspresi kegembiraan atas kelahiran Nabi dan Mahallul Qiyam dianggap memiliki kesakralan untuk mencapai tujuan tertentu seperti keselamatan, keberkahan dan lain sebagainya (Wawancara dengan HT, pimpinan pesantren, Bandung, 20/01/2020).

Menurut Sayyid Muhammad Bin 'Alawi al-Maliki al-Hasany, menyatakan bahwa imam alBarzanji dalam kitab maulidnya yang berbentuk prosa menyatakan sebagian para imam ahli hadis yang mulia itu menganggap baik (istihsan) berdiri ketika sejarah kelahiran Nabi saw, betapa beruntungnya orang yang mengagungkan Nabi saw dan menjadikan hal itu sebagai puncak tujuan hidupnya (Sholikhin, 2010). Sikap berdiri diambil sebagai gerakan tubuh untuk mengungkapkan sikap menghormat kaum muslimin, dan karena kegembiraan dan suka cita atas beliau, serta bersyukur kepada Allah bahwa ia telah mengutus Nabi Muhammad yang menerangi kehidupan manusia, bukan karena beliau yang hadir secara fisik pada saat itu. Jadi, niat yang dipakai adalah untuk menghormati dan menghargai kebesaran pribadi Rasul seakan merasakan keagungan sikap dan kebesaran kedudukannya sebagai Rasul. Oleh karena itu pesertalah yang berusaha menghadirkan Nabi dalam dirinya (Wawancara dengan HT, pimpinan pesantren, Bandung, 20/01/2020).

Shalawat yang dilantunkan adalah طلع البدر علينا shalawat ini telah ada sejak Nabi tiba di Yasrib dalam peristiwa hijrah shalawat yang dibaca oleh kaum Anshar. Selain itu karena shalawat yang dilantunkan ini syair-syairnya tidak terlalu panjang jadi tidak menggunakan waktu yang alan apakagi 
banyak kegiatan-kegiatan setelah marhabaan (Wawancara dengan HT, pimpinan pesantren, Bandung, 20/01/2020).

\section{Kegiatan Akhir}

Pembacaan pasal ke 18 selesai, maka pembacaan do'a penutup kembali dibacakan oleh imam. Ketika pembacaan kitab al Barzanji selesai, maka seluruh partisipan dipersilahkan menyantap makanan yang telah tersedia sebelumnya. Setelah para partisipan menyantap makanan yang ada, maka pemilik rumah ataupun anggota keluarga menyediakan makanan ringan atau istilah sekarang "pencuci mulut" berupa kopi, teh, kue-kue tradisional dan rokok.

Ketika penulis berinteraksi pada acara marhabaan, maka penulis menganalisis secara alamiah bahwa, pada saat itu pulalah seluruh partisipan berinteraksi sambil bersantai menggunakan momen itu untuk membicarakan hal yang urgen berbagai masalah-masalah aktual, misalnya masalah pertanian, masalah ekonomi, kesehatan, masalah keagamaan, pendidikan, serta kesehatan keluarga masing-masing dan sesekali diselingi dengan humor.

Setelah tahapan itu selesai, maka seluruh partisipan pamitan untuk pulang atas selesainya prosesi marhabaan tersebut maka tidak lupa pula, anggota keluarga memberikan cinderamata berupa sedekah yang dimasukkan di dalam amplop secara Cenning Ati (seikhlasnya) sebagai bentuk terimakasih kepada seluruh partisipan yang Penjelasan di atas, mengakhiri uraian prosesi umum acara marhabaan dan sesuai hasil pengamatan penulis selama berinteraksi pada acara ini, dapatlah diketahui bahwa secara garis besar pelaksanaan acara marhabaan itu pada dasarnya hampir sama di setiap acara/momentum yang berkembang di Jawa Barat khususnya di Ponpes Al-Quwwah Kota Bandung.

\section{Simbolisme Marhabaan}

Kata simbol berasal dari kata Yunani Simbolon yang berarti tanda atau ciri yang memberitahu sesuatu hal kepada seseorang. WJS Poerwadarwinta (Poerwadarminta, 1954) dalam kamus Umum Bahasa Indonesia menyebutkan bahwa simbol atau lambang ialah sesuatu seperti: tanda, lukisan, perkataan, lencana dan sebagainya, yang menyatakan sesuatu hal yang mengandung maksud tertentu, misalnya warna putih menyimbolkan kesucian. Di dalam Kamus Filsafat, Lorens Bagus (Lorens, 1996) menyebutkan simbol, yang dalam Bahasa Inggris: Symbol, dalam bahasa Latin: Simbolicum, dan dalam bahasa Yunani: Simbolon, dari Symballo (menarik kesimpulan, berarti, memberi kesan).

Sejarah Pemikiran istilah ini mempunyai dua arti yang sangat berbeda. Pemikiran dan praktek keagamaan, simbol-simbol biasa dianggap sebagai gambaran kelihatan dari realitas transenden, sedangkan system pemikiran logis dan ilmiah, lazimnya dipakai dalam arti tanda abstrak. Bagus (Lorens, 1996) mengungkapkan arti simbol sebagai hal yang sering terbatas pada tanda konvensional, yakni sesuatu yang dibangun oleh masyarakat atau individu-individu dengan arti tertentu dengan standar yang disepakati atau dipakai anggota masyarakat itu.

Pengertian simbol ini perlu dibedakan dengan isyarat dan tanda. Insyarat ialah sesuatu hal atau keadaan, yang diberitahukan oleh subjek kepada objek, agar si objek mengetahui pada saat itu juga. Tanda merupakan suatu hal atau keadaan yang menerangkan atau memberitahukan objek kepada si subjek. Oleh karena itu, hubungan yang terjadi antara simbol dan objeknya tidak sederhana seperti hubungan antara tanda dan objeknya, tetapi ada kebutuhan dasariah akan simbolisasi (van den Boogert, 2017).

\section{Simbolisme Pencukuran Rambut Bayi}

Islam merupakan agama dakwah,yang mana Islam sebagai satu sistem nilai yang bersumber dari Allah. Kebenaran Islam bersifat absolut, tunggal, eternal, dan universal. Karena itu, Islam diformat dan deprogram Allah bukan untuk kepentingan-Nya, melainkan untuk kepentingan manusia menuju keselamatan dan kesejahteraan hidup, baik di dunia maupun akhirat (Syarbini, 2011).

Islam mensyariatkan untuk mencukur rambut bayi ketika sudah dilahirkan, dan biasanya pencukuran rambut bayi itu dilaksanakan pada hari ketujuh. Para ulama ada yang berbeda pendapat 
tentang hukum pencukuran rambut bayi tersebut. Akan tetapi sebagian besar para ulama membolehkan pencukuran rambut bayi. Mencukur rambut adalah anjuran Nabi yang sangat baik untuk dilaksanakan ketika anak yang baru lahir pada hari ketujuh. Rasulullah SAW bersabda yang artinya "Setiap anak terikat dengan aqiqahnya. Pada hari ketujuh disembelihkan hewan untuknya, diberi nama, dan dicukur" (HR. al-Tirmidzi). Dalam kitab al-Muwaththa, Imam Malik meriwayatkan bahwa Fatimah menimbang berat rambut Hasan dan Husein lalu beliau menyedekahkan perak seberat rambut tersebut (Rahmat, 2015).

Terkait banyak atau tidaknya rambut yang harus cukur sebenarnya tidak ada ketentuan apakah harus digundul atau tidak. Tetapi yang jelas pencukuran tersebut harus dilakukan dengan rata, tidak boleh hanya mencukur sebagian kepala dan sebagian lain dibiarkan. Sudah tentu semakin banyak rambut yang dicukur dan ditimbang semakin berat maka semakin besar pula sedekahnya.

Rasulullah SAW bersabda: "Setiap anak itu tergadaikan dengan aqiqahnya, disembelih sembelihan darinya pada hari ketujuh, dicukur rambutnya, dan diberi nama." (Hadist sahih riwayat At-Tirmidzi).

Praktik mencukur rambut bayi yang baru dilahirkan sebenarnya bukanlah hanya sekadar tradisi yang sudah lama melekat di masyarakat, akan tetapi juga anjuran dan ajaran agama. Pencukuran rambut bayi ini biasanya dilakukan bersamaan dengan marhabaan, tentu di balik tradisi mencukur rambut bayi terdapat banyak manfaat, banyak nilai positif terutama bagi kesehatan bayi.

Tradisi mencukur rambut bayi merupakan suatu perayaan bagi sebuah keluarga karena hadirnya sebiah pelita hati, permata baru. Dalam acara ini biasanya warga yang mengadakan tradisi ini mengundang kerabat dekat, sahabat atau ettangga untuk ikut menyaksikan kebahagiaan yang dirasakan keluarga itu sekaligus memberikan nama yang bagus yang memiliki makna doa, supaya setiap orang yang memanggil namanya ikut mendoakan sesuai nama si bayi. Biasanya acara itu dilakukan dalam acara tasmiyah atau aqiqahan dalam agam Islam. Acara tersebut dikemas dalam bentuk syukuran sambil membaca kitab al-Barzanji (marhabaan). Kemudian ada juga keluarga yang mengundang grup rebana, marawis untuk melengkapi acara tersebut (Rahmat, 2015).

Tradisi pencukuran rambut bayi tersebut sambil diiringi dengan bunyi tepakan rabana sambil ngopi bersama dengan jamaah yang mengikuti acara tersebut. Dengan di bunyikannya seni musik hadroh membuat kesemangatan yang mampu memotivasi seluruh yang hadir untuk tetap konsisten duduk sampai acara tersebut selesai. Keadaan semakin rame apabila sang ayah keluar dari kamarnya sambil mengendong sang buah hatinya, diayun-ayun sebentar, tidak lama kemudian masyarakat yang mengikuti acara tersebut semuanya berdiri sambil melantunkan shalawat yang ditujukan kepada Nabi Muhammad SAW. Acara pencukuran rambut bayi pun dimulai. Semua tamu undangan beserta masyarakat diberi kesempatan untuk memotong rambut bayi tersebut. Sang bayi dibawa oleh ayahnya berkeliling ditengah-tengah masyarakat untuk dicukur rambutnya, kemudian rambut yang telah digunting itu dimasukkan ke dalam sebuah wadah yang terisi air dan berbaga macam bunga (Wawancara dengan HM, pengajar pesantren, Bandung, 16/03/2020).

Menurut KH. Hasan Tojiri praktik pencukuran rambut bayi bukan hanya saja dilaksanakan di lingkungan Pesantren Al-Quwwah saja, akan tetapi acara tersebut bisa ditemukan di berbagai daerah yang ada di Indonesia. Pencukuran rambut bayi merupakan salah satu praktek keagamaan berbasis kearifan lokal, bayi yang baru dilahirkan biasanya dikumandangkan adzan pada telinga kanannya dan iqamah pada telinga kirinya, hal ini memberikan pemahaman agar sang bayi ketika sudah dewasa dapat mengingat sang pecipta-Nya dan beribadah kepada-Nya. Mencukur rambut bayi merupakan ajaran yang dipraktekan oleh Rasulullah SAW. Setelah dicukur, rambut tersebut ditimbang, Setelah ditimbang kemudian berat rambut tersebut di ukur dengan nilai harga emas pada saat itu. Contoh bera rambutnya $1 \frac{1}{2}$ gram maka orang tua tersebut mengeluarkan shodaqoh kepada fakir miskin, anak-anak terlantar atau masyarakat yang berhak menerima sedekah tersebut saharga $1 / 2$ gram emas, dan emas tersebut diuangkan terlebih dahulu. Jadi yang diberikan kepada orang yang membutuhkan itu adalah berupa uang (Wawancara dengan HT, pimpinan pesantren, Bandung, 16/03/2020).

Selain itu manfaat dari mencukur rambut bayi dalam agama Islam sebagai berikut: (a) Dengan mencukur rambut bayi maka dapat mencegah gangguan visual mata bayi. Sebab bila rambut terlalu panjang maka akan menutup mata dan mengganggu penyesuaian bayi terhadap lingkungannya. (b) 
Bila rambut bayi panjang dikhawatirkan akan membuat iritasi dan luka di liang telinga bayi. (c) Setelah mencukur rambut maka akan mudah melihat penyakit di kulit kepada sang bayi seperti lukam iritasi, maupun penyakit lain. (d) Menjadikan rambut lebih bercahaya, indah, kuat, maupun sehat merupakan etika mencukur rambut bayi dalam agama Islam rahmat bagi setiap manusia (Divika, 2019).

\section{Simbolisme Pesan dalam Perangkat Marhabaan}

Perangkat budaya marhabaan penuh dengan simbolisme pesan-pesan moral kehidupan masyarakat. Simbol kehidupan disampaikan dalam bentuk, rupa, warna, jenis yang disajikan dalam budaya ini. Pesan solidaritas, keyakinan, keutuhan, keluarga, keamanan, kemakmuran dan tanda syukur kepada Allah SWT. Perangkat yang digunakan dalam acara marhabaan tersebut mengandung pesan-pesan keagamaan.

\section{Cau (Pisang)}

Pisang menjadi sajian yang disertakan dalam budaya marhabaan dengan makanan yang lainnya. Argumentasi masyarakat memilih pisang sebagai salah satu makanan dalam tradisi marhabaan karena masyarakat memiliki perspektif bahwa pisang merupakan salah satu buah yang banyak manfaatnya dan sangat diperlukan dalam kehidupan sehari-hari sehingga tidak bisa dipisahkan dalam kehidupan masyarakat.

Kegunaan pohon pisang dapat ditinjau dari berbagai bagian pohon yang memiliki manfaat bagi kehidupan manusia, mulai dari batang, jantung, buah dan daunnya. Tanaman pisang juga sebagai simbol keluarga. Simbol kehidupan yang dipercaya agar tumbuh dan berkembang menjadi keluarga besar karena pohon pisang menggambarkan sebagai keutuhan kehidupan keluarga yang selalu dikelilingi dan diapit oleh anak-anaknya, bila ada yang meninggal maka ada yang lahir. Dengan kata lain, budaya yang dijalankan oleh para santri Al-Quwwah dan masyarakat bila ada pelakunya yang sudah meninggal maka akan ada generasi penerus di sekelilingnya yang melanjutkan tradisi itu agar tetap terjaga keberadaannya.

Islam adalah agama dakwah yang mana Islam mengajak dan mengharapkan sebuah keluarga yang harus tumbuh dan berkembang serta memiliki kualitas agar amanah Allah menjadikan manusia sebagai Kalifah Fi Al-Ard akan berjalan sesuai dengan tuntunan serta ajakan agama. Kemudian manusia diberi tugas oleh Allah untuk memberi manfaat dan mengajak kepada kebaikan kepada orang-orang yang berada di sekitar kita, apalagi dalam hadis Nabi yang menjelaskan bahwa "sebaikbaiknya kalian adalah yang banyak memberikan manfaat kepada sesama manusia". Jadi intinya kita harus memberikan manfaat di sekeliling kita dengan kemampuan yang kita miliki sebagai wujud hubungan sosial kita baik.

\section{Ulen (Nasi Ketan)}

Nasi ketan atau dalam bahasa sundanya adalah ulen', pemilihan nasi ketan dalam acara marhabaan memiliki alasan simbolik. Nasi ketan (ulen) merupakan makanan favorit masyarakat Sunda. Ulen' bermakna kekuatan dan persatuan yang kokoh. Meskipun berasal dari butiran kecil yang sangat keras dan terpisah, namun setelah dimasak serta diolah maka akan mampu merekatkan satu sama lain. Simbol ini dimaknai bahwa meskipun masyarakat terpisah-pisah namun bisa bersatu dalam kekuatan yang besar. Selain itu ulen yang mampu bertahan lama dimaknai sebagai kekuatan atas persatuan dan kebersamaan harus mampu bertahan lama demi mewujudkan keharmonisan, kebahagian, dan kecintaan. Allah berfirman dalam surah Ali Imran/3: 103:

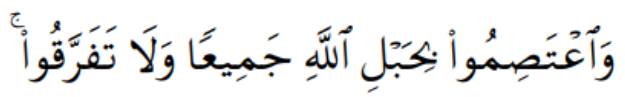

"Dan berpegang teguhlah kamu semuanya pada tali (agama) Allah, dan janganlah kamu bercerai berai" (Departemen Agama, 2009). 
Pesan simbolik di atas sangat sejalan dan sejalin dengan ajaran agama Islam tentang menjaga kesatuan dan persatuan. Persatuan yang kuat akan membawa hikmah tersendiri bagi umat Islam karena kebesaran agama Islam bukan dilihat dari kuantitasnya akan tetapi kebersamaan dan persatuannya berkualitas. Islam sebagai agama yang di ridhai oleh Allah harus memiliki kekuatan yang tangguh dan kokoh dalam mewujudkan persaudaraan serta persatuan diantara umat Islam. Pesan dari ulen' yang diharikan dalam acara marhabaan supaya semua hadir dalam acara tesebut dan mampu mengambil hikmah dari yang disajikan.

\section{Kue-kue tradisional}

Penjamuan tidak akan lengkap tanpa adanya penyajian kue-kue tradisional sebagai pencuci mulut para peserta tradisi marhabaan. Kue-kue tradisional tidak dapat dipisahkan dalam acara karena sudah menjadi tradisi masyarakat setempat. Kue-kue yang ditenukan adalah, Ranginang, Ali Agrem, Dodoldodol, Wajit, Bugis, dan lain-lain. Hal tersebut merupakan makanan khas Jawa Barat yang selalu dijumpai dalam acara marhabaan di Pondok Pesantren Al-Quwwah. Perlu di komunikasikan juga bahwa kehadiran makanan khas tersebut, merupakan usaha masyarakat untuk memaduan tradisi dengan kebudayaan Islam dan adanya makanan khas ini bukanlah pengaruh dari mahabraan bahkan tidak ada kaitannya. Marhabaan itu tetap menjadi khas Islam tetapi makannanya tidak mesti harus demikian. Karena ketika salah satu makanan ini tidak dihadirkan atau semuanya tidak ada, maka acara marhabaan ini tetap dilaksanakan dan tidak ada keyakinan-keyakinan mengarah kepada kemusyrikan.

\section{Cai Herang (Air Putih)}

Cai herang atau air putih merupakan salah satu minuman yang selalu dihadirkan dalam berbagai macam acara khususnya acara marhabaan. Pemilihan air putih ini memiliki alasan tersendiri bagi para santri dan masyarakat setempat. Mereka memiliki perspektif bahwa air putih itu memberikan manfaat yang positif bagi kehidupan manusia, karena kalau kehidupan tanpa ada air maka semua manusia akan merasakan kehausan bahkan tidak akan ada kehidupan sama sekali. Makna simbolik air putih ini memberikan pesan kepada kita bahwa manusia itu harus memiliki hati dan pikiran yang bersih dalam melakukan segala perbuatan. Dengan kesucian itulah maka akan melahirkan keikhlasan dalam beribadah. Air putih juga sering digunakan sebagai obat dalam menyembuhkan penyakit. Biasanya air putih itu diberikan doa-doa oleh kyai atau orang-orang yang dipercaya dalam menyembuhkan penyakit melalui pelantara doa tersebut. Oleh karena itu, air putih yang sudah diberikan doa mengandung kemistikan yang dipercayai oleh sebagian masyarakat. Akan tetapi air putih tersebut tidak mengandung kemusyrikan selagi masyarakat menganggap bahwa air putih tersebut sebagai pelantara untuk menyembuhkan penyakit tetapi tetap hakikatnya Allah yang menyembuhkan (Wawancara dengan HT, pimpinan pesantren, Bandung, 17/01/2020).

Sedangkan perangkat-perangkat yang digunakan pada acara marhabaan adalah diantaranya menyan. Menyan merupakan salah satu perangkat mistik yang dipercaya oleh sebagian masyarakat yang dapat menghadirkan makhluk halus. Tetapi berbeda dengan menyan yang digunakan pada acara marhabaan. Masyarakat memiliki paradigma bahwa menyan bisa mengusir nyamuk dan bisa membuat wangi ruangan, sehingga masyarakat bisa nyaman dalam melaksanakan tradisi tersebut (Negara, 2017). Menurut kamus Bahasa Indonesia definisi dari menyan/dupa adalah kemenyan, setanggi, dan sebagainya yang apabila dibakar asapnya berbau harum. Sedangkan Mendupati artinya mengasapi dengan membakar menyan dan Pedupan adalah tempat dupa anglo (kecil) tempat membakar menyan/dupa (Saputra, 2017).

Pembakaran menyan sebenarnya berasal dari keyakinan-keyanikan masyarakat dulu yang belum tersentuh oleh agama Islam dan digunakan untuk memanggil roh-roh. Ketika Islam hadir di tengah pergumulan budaya yang memiliki praktek kemusyrikan maka Islam berinteraksi dan bernegisiasi dengan pendekatan yang sesuai dengan kondisi saat itu. Secara konsekwensi logis maka diberikanlah dogma yang bersifat Islam serta tidak secara langsung menolak tradisi sebelumnya. Pembakaran menyan dalam acara marhabaan tidaklah dijadikan lagi sebagai pemanggil roh-roh atau yang bersifat musyrik tapi tujuanya yaitu sebagai pengharum ruangan dan mengusir nyamuk. 
Kemudian makna simbolik menyan bisa memberikan pesan kepada kita supaya hidup ini bisa memberikan kewangian kepada diri sendiri maupun kepada orang lain. Wangi disini dimaknai sebagai perilaku baik yang dapat mengajak orang lain untuk melakukan aktivitas yang positif sesuai dengan petunjuk Allah dan ajaran Rasulullah SAW. Kemudian kita harus bisa bergaul dan berinteraksi dengan orang-orang yang shaleh dan baik, tujuannya adalah supaya kita terbawa olehnya dan supaya masyakat memiliki pandangan yang positif kepada kita, sehingga hadirnya kita ditengah-tengah masyarakat tidak membawa keburukan, tetapi bisa menyadarkan manusia untuk kembali kepada jalan yang diridhai Allah (Wawancara dengan HT, pimpinan pesantren, Bandung, 17/01/2020).

Melihat kepada kondisi dulu yang belum modern maka sangat memungkinkan dan efektif jika menyan dijadikan pengharum ruangan. Peneliti pun sepakat dengan pernyataan informan tentang pembakaran menyan dalam acara marhabaan tapi ditarik dalam konteks kekinian, alangkah baiknya menyan itu digantikan oleh parfum ruangan yang lebih modern, karena substansinya adalah mengharumkan ruangan. Akan tetapi jika masih ada yang melakukan pembakaran menyan dalam acara marhabaan maka itupun tidak menjadi persoalan kerena sudah menjadi jejak sejarah. Hal ini menjadi ciri khas Islam Nusantara.

\section{Kesimpulan}

Budaya marhabaan di Pondok Pesantren Al-Quwwah Kota Bandung merupakan potret dari suatu tradisi yang sudah membudaya khususnya di Kalangan Nahdlatul Ulama (NU). Dalam prosesnya, tradisi ini diawali dengan doa, pembacaan kitab al-Barzanji, kemudian diakhiri dengan pembacaan doa. Selain itu tradisi ini mengandung beberapa makna simbol yang memberikan informasi tentang pesan moral seperti pencukuran rambut bayi, makna simbolik pisang, makna simbolik menyan, makna simbolik ulen (nasi ketan), makna simbolik kue tradisional, dan makna simbolik air putih. Pesan moralnya misalnya adalah bahwa manusia diberi tugas oleh Allah untuk memberi manfaat dan mengajak kepada kebaikan kepada orang-orang yang berada di sekitarnya, juga bahwa kebaikan itu harus diturunkan kepada generasi sesudahnya. Kajian ini menegaskan bahwa ada keterkaitan kultural antara ajaran Islam dengan budaya lokal yang terus dikembangkan oleh umat Islam di Indonesia.

\section{Referensi}

Abdul Fatah, M. (2008). Tradisi Orang-Orang NU. Yogyakarta: Pustaka Pesantren.

Akbar, S. P., \& Usman, H. (2006). Metode Penelitian Sosial. Jakarta: Bumi Askara.

Bachmid, G. (2014). Kitab" Barzanji" dalam Perspektif Masyarakat Muslim Di Manado, Sulawesi Utara. LAKTUR. Jurnal Penelitian Lektur Dan Khazana Keagamaan, 12(2), 419-440.

Departemen Agama. (2009). Al-Qur'an dan terjemahan. Jakarta: Departemen Agama.

Dillistone, F. W. (1986). The power of symbols in religion and culture. New York: Crossroad.

Divika, A. H. Y. (2019). Adat dalam Perspektif Dakwah(Studi Etnografi Tradisi Pemberian Nama Anak Dalam Suku Melayu). At-Tadabbur: Jurnal Penelitian Sosial Keagamaan, 9(1), 123-138.

Ghony F., M. D. A. (2016). Metodologi penelitian kualitatif. Yogyakarta: Ar-Ruzz Media.

Junaid, M. (2005). Tradisi Barzanji Sya'ban Masyarakat Bugis Wajo Tanjung Jabung Timur. Kontekstualita: Jurnal Penelitian Sosial Keagamaan, 20(1), 79-92.

Koentjaraningrat, K. (2004). Kebudayaan, mentalitas dan pembangunan. Jakarta: Gramedia Pustaka Utama.

Librianti, E. O. I., \& Mukarom, Z. (2019). Budaya Tahlilan sebagai Media Dakwah. Prophetica: Scientific and Research Journal of Islamic Communication and Broadcasting, 5(1), 1-20.

Lorens, B. (1996). Kamus Filsafat. Jakarta: Gramedia.

Lubis, N. H. (2011). Sejarah Perkembangan Islam di Jawa Barat. Bandung: Yayasan MSI [Masyarakat Sejarawan Indonesia].

Mulyana, D. (2002). Ilmu Komunikasi: Suatu pengantar (1st ed.; Muchlis, ed.). Bandung: Remaja Rosdakarya.

Mustari, M., \& Rahman, M. T. (2012). Pengantar Metode Penelitian. Yogyakarta: Laksbang Pressindo.

Negara, W. S. (2017). Nilai-nilai Pendidikan Islam dalam Tradisi Mabbarasanji pada Masayrakat Bugis di Kelurahan Watampone Kecamatan Tanete Riattang Kabupaten Bone. Universitas Islam Negeri Alauddin Makassar.

Poerwadarminta, W. J. S. (1954). Kamus umum bahasa Indonesia. Jakarta: Perpustakaan Perguruan Kementerian PP dan K.

Raffles, T. S. (2018). The history of Java (Vol. 1). London: John Murray. 
Rahman, T. (2013). “Indianization" of Indonesia in an Historical Sketch. International Journal of Nusantara Islam, $1(2), 56-64$.

Rahmat, A. (2015). Tradisi Potong Rambut Gorontalo (Hundingo). IBDA: Jurnal Kajian Islam Dan Budaya, 13(2), $86-96$.

Rosyid, N. (2012). Bershalawat Bersama Habib: Transformasi Baru Relasi Audiens Muslim NU Di Indonesia. Jantra, 7(2), 135-144.

Sambas, S., \& Aripudin, A. (2007). Dakwah Damai Pengantar Dakwah Antar Budaya. Bandung: PT. Remaja Rosdakarya.

Saputra, E. W. (2017). Makna Dupa dalam Tradisi Assuro Ammaca di Desa Bone Kecamatan Bajeng Kabupaten Gowa. Universitas Islam Negeri Alauddin Makassar.

Sholikhin, M. (2010). Ritual dan Tradisi Islam Jawa: Ritual-ritual dan tradisi-tradisi tentang kehamilan, kelahiran, pernikahan, dan kematian dalam kehidupan sehari-hari masyarakat Islam Jawa. Yogyakarta: Penerbit Narasi.

Sujati, B. (2019). Tradisi Budaya Masyarakat Islam di Tatar Sunda (Jawa Barat). Ishlah: Jurnal Ilmu Ushuluddin, Adab Dan Dakwah, 1(1), 37-51.

Sumpena, D. (2012). Islam dan budaya lokal: Kajian terhadap Interelasi Islam dan budaya Sunda. Ilmu Dakwah: Academic Journal for Homiletic Studies, 6(1), 101-120.

Syarbini, H. A. (2011). Islam dan Kearifan Lokal (Local Wisdom): Menelusuri Nilai-nilai Islam dalam Praktik Ritual Adat Masyarakat Banten. The 11th Annual Conference on Islamic Studies, 170.

van den Boogert, J. (2017). The role of slametan in the discourse on Javanese Islam. Indonesia and the Malay World, 45(133), 352-372.

Wahidi, R. (2015). Budaya dan Agama sebagai Identitas Islam Nusantara; Kajian atas Tradisi Marhaba'an/Maulid nabi di Tanah Sunda. Madania: Jurnal Ilmu-Ilmu Keislaman, 5(2), 200-218.

Wanta, S. (1991). KH Abdul Halim dan Pergerakannya. Majalengka: PB PUI Majelis Penyiaran Penerangan dan Dakwah.

Wibisono, M. Y. (2013). Keberagaman Masyarakat Pesisir: Studi Perilaku Keberagaman Masyarakat Pesisir Patimbun Kecamatan Pusakanegara Kabupaten Subang Jawa Barat. UIN Sunan Gunung Djati Bandung.

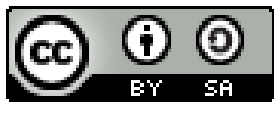

(C) 2020 by the authors. Submitted for possible open access publication under the terms and conditions of the Creative Commons Attribution (CC BY SA) license (https://creativecommons.org/licenses/by-sa/3.0/). 
Halaman ini sengaja dikosongkan 